\title{
THE ETHICAL BASIS OF JURISPRUDENCE
}

"Thou shalt love thy neighbor as thyself" is the second part of that Great Commandment upon which hangs all the law. The first part commands supreme love to God, and the second part commands each person to love self and neighbor equally. While, in a certain sense, this command of love to persons-God, self and neighbor-constitutes one law, yet, for our purpose, we wish to consider only the command, "Thou shalt love thy neighbor as thyself," and that, too, in its relation to jurisprudence.

This law requiring man to love himself and his neighbor equally is not an arbitrary command. It is only the announcement of a fundamental principle in the moral world. Man can love himself only by loving others, and he can love others only by loving himself. Persons are so constituted that mutual helpfulness is a necessary condition precedent to moral growth and social progress.

To love self, as here commanded, means to serve self, to make the most of self, to develop all the powers, faculties, and susceptibilities of self; to perfect self physically, intellectually, morally and spiritually. "Be ye therefore perfect" is the command imposed upon self. This is the individual's standard of excellence. In this manner and to this extent man must love or serve himself. The personal perfection, secured by obedience to the law of love, and the happiness incident to its attainment and possession constitutes man's supreme good, his highest wellbeing, his bonum summum and bonum ultimatum.

In doing this man is egoistic; he is loving self. And from necessity man must love self before he can love or serve others. He must get before he can give. Before he can give money to the needy he must get it; before he can impart knowledge to the ignorant he must himself acquire it; before he can inspire others with high moral and spiritual purposes he must himself possess them. Man can hold before others the ideals of excellence in intellectual attainments and in moral conduct, only after he has conceived those ideals in his own thought. In possessing himself of wealth, knowledge, high ideals, lofty purposes, and all other instrumentalities of power man is loving self. He is preparing himself for service to God and man. 
While it is necessary for man to be egoistic before he can be altruistic, it is equally necessary that he should be altruistic before he can attain his own highest well-being. In the realm of moral conduct men must consider both their duties and their rights, and only as one performs his duties and thereby accords to others their rights can he best love or serve himself. Only by performing his duties can man make the most of himself. Only by recognizing the rights of his neighbor can man comply with the law of love. The love commanded by the law consists in deeds, not in feelings only.

In paying just claims due his neighbor, compensating him for injuries negligently inflicted, returning property borrowed from his neighbor at the time agreed upon, delivering property sold to his neighbor at the place and time stipulated, speaking truthfully of his neighbor when he has a right to the truth, imparting knowledge to his neighbor when he has a right to it, and in many cases, bestowing gratuitous services upon his neighbor hoping for nothing in return, as in caring for the sick, the insane, the feeble-minded and those otherwise unfortunate and incapacitated, in doing these deeds, I say, man is loving his neighbor as the law requires, and at the same time in doing these deeds man is loving himself, for only by such conduct can man attain his own highest good. To serve and love self man must be just toward his neighbor; he must look with equal favor upon his own duty and his neighbor's right. It is in this way that man loves himself, serves his neighbor as himself, and thus complies with the law of love.

But performing one's duty and satisfying a neighbor's right in regard to debts and injuries and many other moral demands of a reciprocal character is what we call justice, so that an act of justice is an act of love to one's self and neighbor. While we say in such cases that a man acts according to the principle of justice, we may say with equal truth that he acts according to the principle or law of love. They are not two separate principles, but they are one and the same. They are identical. The principle of justice is the law of love applied in those transactions involving reciprocal rights and duties.

Again, love to self often demands that one bestow favors upon a neighbor hoping for nothing in return. Only by bestowing gratuitous services upon the needy can one comply with the law of love, and thus take a step toward making the most 
of himself. Such occasions abound in every human life. The true interests of self are, in such cases, subserved by rendering gratuitous services to those needing food, clothing, comfort, shelter, knowledge, encouragement, inspiration or other benefaction, in some of its thousand forms. But when one thus acts gratuitously toward a neighbor, we say he is applying the principle of benevolence, when, in fact, he is complying with the law of love. Here again the principle of benevolence and the law of love are identical. It is the law of love being applied in a transaction where self renders to neighbor a gratuitous service.

Further, too, one is often called upon to impart information to a neighbor, and he can best subserve his own and his neighbor's interests only by conforming his statements strictly to the facts in the case. In this manner one maintains his own spiritual integ-. rity, adds to his moral value, and serves his neighbor by meeting a need which he is experiencing. But here again we say that he is acting upon or applying the principle of veracity, though in fact he is applying the law of love. The two are identical. And, so it appears that the specific principles of justice, benevolence and veracity are but other names applied to the one all-comprehensive law of love. These specific principles, which stand for so much, and seem so individual, separate and distinct in our practical ethics, are, in reality, but the single law of love known by three different names, according to the different circumstances under which it is applied, as a lawyer when trying cases at the bar is called a practitioner, when sitting on the bench is called a judge, and when writing learned treatises upon jurisprudence is called a jurist-one person with three names, according to the occupations in which he is for the time being engaged. And so the specific moral principles of gratitude, mercy and others are identical with that all-comprehensive law. St. Paul expresses this identity of the general law and the specific principles as follows:

"The commandments: 'Thou shalt not commit adultery, Thou shalt not kill, Thou shalt not steal, Thou shalt not covet' and whatever other commandment there is are all summed up in these words, "Thou shalt love thy neighbor as thou dost thyself.' " 1

This all-comprehensive moral law manifesting itself in the principles of justice, benevolence, veracity and in other specific virtues is not an arbitrary comimand spoken by Christ, but it is a constitutive element in the moral constitution of man. It was a

I Romaris, 13-9. The 2oth Century Nं: T. 
well-known moral law among the Jews long before Christ's advent. And though not formulated as stated by the Jews, the essential fact that man should regard the interests of others as well as his own, was recognized by the ancients both East and West and expressed in their respective writings. Cicero said, "One thing ought to be aimed at by all men, that the interest of each individual, and of all collectively, should be the same, for if each should grasp at his individual interest, all human society would be dissolved." And, further, he says, "Nature enjoins this, that a man should desire to consult the interests of a man, whoever he is, for the very reason that he is a man." 2 And prior to his day, the stoics, according to the same author, taught "that men are created for the sake of men, that they may mutually do good to one another." $s$

And Sir William Jones assures us that the wise men of the world, East as well as West, were not ignorant of the two great maxims, "That we must act in respect to others as we should wish them to act in respect to ourselves," and "That instead of returning evil for evil we should confer benefits even on those who injure us." He says the first maxim is implied in a speech of Lysias, expressly stated by Thales and Pittacus, and that he has read it word for word in the writings of Confucius."

It is claimed even by modern evolutionists that the idea of oughtness, this altruistic sense of duty, of debt to others, the breaking away from selfishness and devotion to another's interests arose necessarily within and formed a conspicuous part of the age-long Cosmic process itself; and that, indeed, this moral law of love is not only part and parcel of the Cosmic process, but that it is "its crown and consummation," that a historical survey of the genesis of Humanity "shows very forcibly that a society of Human Souls living in conformity to a perfect Moral Law is the end toward which the Cosmic process has all along been aiming." 5

"Thou shalt be just and benevolent, and veracious and merciful, and forgiving toward thy neighbor" is only another way of saying, "Thou shalt love thy neighbor as thyself." But jurisprudence does not undertake to enforce all that this moral law requires.

2 Cicero's Offices, Book III, Chapter 6.

3 Cicero's Offices, Book I, Chapter 7.

4 Works, Vol. III, pages 243, 245.

"Fiske, "Through Nature to God." 
Justice and benevolence and veracity and the other virtues have two sides-the subjective and the objective. Jurisprudence deals with the objective. It deals primarily with the outward act, not with the inward disposition and purpose of the actor. And again jurisprudence does not regard all unjust, uncharitable, and deceitful outward conduct, but it does concern itself with outward conduct affecting a neighbor's rights to life, liberty and property; enforces benevolent treatment of the weak and destitute neighbor; and compels compensation from one who has injured his neighbor by false, deceitful and misleading statements and behavior. It is not too much to claim that the great bulk of our courts' work involves the principles of justice, of benevolence and of veracity in some of their varied aspects, and as these principles are identical with the law of love, the courts are in reality requiring obedience, in outward act at least, to the all-comprehensive. law, "Thou shalt love thy neighbor as thyself."

Again, while the Federal and State constitutions of our union declare that they are ordained "to establish justice," they also declare that they are ordained "to promote the general welfare." These are the two comprehensive ends for which civil government is organized. Directly or impliedly they embrace the objects for the attainment of which the constitution, statutes, ordinances, and the systems of law and equity are provided. And as all this civil machinery constitutes a part of jurisprudence, and is devoted to the establishment of justice and the promotion of the general good of the people, it, too, is employed in the same sacred and moral effort to secure obedience to the same all-comprehensive law.

Viewed in the light of this great moral law, jurisprudence takes on a richer color and assumes a superior dignity. It is no other than a means for securing social harmony and lifting mankind up toward the exalted state of perfect righteousness and peace of which we are told the kingdom of heaven consists. All who are engaged in constructing, improving and administrating the law-the stateman, the legislator and especially the judge and the practitioner at the bar should regard themselves as priests of the law set aside and consecrated to a holy calling. "When all men do their duties, then all men will have all their rights" and therein we behold the highest possible state of human society. This goal can be attained only by compliance with this allcomprehensive moral law of love or service. 
"Tf this is true, the advantages gained by recognizing the fact are many. It makes jurisprudence a branch of applied ethics; it gives to jurisprudence itself the highest possible dignity; it raises the administration of justice from a selfish scramble by litigants and counsel for unrighteous ends, to a dignified effort on the part of the judge, counsel and advocate, to discover where the golden thread of moral principle runs in the complicated affairs of human life, and to settle the rights of the parties interested according to that principle; it dignifies the office of the judge, by making him a priest at the altar of moral law, and it raises the office of counsel to the exalted life work of one devoted to the advocacy of unselfish love in the complicated details of human life. Judge and counsel together become the unselfish arbiters of the conflicting interests of their fellowmen, ever seeking to discover and satisfy the demands of the all controlling law of love. From such a conception of jurisprudence, and from such a conception of its administration, what judge or advocate or even what minor officer of the court can fail to gain an uplifting and ennobling inspiration?"' 6

William S. Pattee.

Dean of the University of Minnesota Laze School.

'Pattee's Essential Nature of Law, page 243. 
